\title{
Development of a career-enabler framework within a South African higher education institution
}

\author{
Anton Grobler*, Elizabeth Cornelia Rudolph and Magdalena Louise Bezuidenhout \\ Unisa Graduate School of Business Leadership, University of South Africa, Pretoria, South Africa \\ *Corresponding author, email: grobla@unisa.ac.za
}

This study developed a preliminary career-enabler framework for use in a higher education setting. A quantitative survey was conducted with a sample of 1392 employees within a higher education institution in South Africa. Structural analysis was performed using exploratory factor analysis. The analysis yielded three enablers with acceptable psychometric properties, namely: self-transcendence, self-enhancement and self-conservation through work motives and needs. Interventions that focus on career-enablers within a higher education institution need to address these three factors.

Keywords: career anchors; career enablers; conversations; framework; higher education

\section{Introduction}

Change has always been a part of individuals' lives, but it seems that the pace of change is accelerating (de Villiers,2009, p. 83). Businesses experience a combination of fast developments in multiple areas economy, technology and society in general. These have wide implications for the management and development of people at work, and especially the planning and management of careers (Baruch, 2003 as cited in de Villiers, 2009, p. 83).This study focuses on tailoring appropriate career interventions, through a career-enabler framework, that are offered in congruence with an individual's orientation as a way of structuring career discussions within a higher education institution.

\section{Career enablers}

Coetzee (2008) posits that career enablers are those capabilities that may help an individual to enjoy a successful career path. Career enablers can be defined as those skills that assist individuals to be more successful in their jobs (Ferreira \& Coetzee, 2010). Career enablers incorporate skills such as applying theoretical constructs in a realistic and creative manner in order to focus attention on innovative ways of doing things (Ferreira, 2012, p. 74). Rajesh \& Ekambaram (2012, p. 5) define a career enabler as a factor that provides support to an employee in the workplace and contributes to their professional development. The latter definition is adopted for the purpose of this study and the departure point from which the higher education career-enabler framework is based. Following on from this, the importance of a career-enabler framework is evident -an organisation needs to understand the factors that would contribute to the professional development of their employees. Two constructs are associated with the notion of career enablers: practical/creative and self/other skills (Coetzee, 2006; 2008). Practical/creative skills include applying existing theoretical constructs in new ways of doing things (Ferreira, Basson, \& Coetzee, 2010, p. 3). The term “self/ other skills" relates to Gardner's (1983) view that personal intelligence consists of interpersonal intelligence (or the ability to understand, honour, empathise with and interact effectively with others) and intrapersonal intelligence (or the ability to understand one's feelings and motivations and exert self-discipline in one's interactions) (Bay \& Lim, 2006; Coetzee, 2007).

\section{Career orientations}

Schein (1978) described career anchors as a pattern of self-perceived talents and abilities, which influence a person's career-related decisions (Schein, 1975; 1978; 1996). Coetzee \& Schreuder (2009) suggest that a person's career self-concepts are grounded in eight categories or anchors: (1) autonomy/independence (a person's need to be free of organisational constraints in order to pursue professional competence); (2) technical/functional competence (motivation to develop one's technical or functional knowledge and expert skill); (3) general managerial competence (desire to attain a managerial level of interpersonal, political, analytical and financial skills) (4) entrepreneurial/creativity (need to create or build); (5) lifestyle (the need to integrate work, family, and self-concerns into a coherent lifestyle); (6) pure challenge (the need to test one's abilities); (7) service/dedication to a cause (the need to align work activities with personal skills and values related to helping society) and (8) 
security/stability (the need for job security (see also Schein, 1978; 1990; 1996).

\section{Career-enabler groups}

As individuals make choices associated with their self-development, family or career, they may become more aware of the values and motives that frame the choices they make. The knowledge of one's career orientation is critically important because of its influence in career choices and its effect on shaping an individual's goals in life. Three career-enabler groups are identified: self-transcendence (through technical and specialised affirmation), self-enhancement (through stretched goals) and selfconservation (through motives of work and needs) (Schein, 1985).

\section{Goal of the study}

The aim of this study was to propose a career-enabler framework which could be used in structuring career discussions within a higher education institution. We sought to explore the three most important career preferences for employees within a higher education institution and to develop a career-enabler framework that will assist the institution with career conversations. The objectives for the study are to:

- determine the number and nature of career anchors individuals from a higher education institution might hold

- determine the three most important career preferences for employees within a higher education institution

- develop a higher education career-enabler framework that will assist the institution with career conversations.

\section{Method}

\section{Participants and setting}

The sampling frame for this study was 4200 employees of a distance education institution in South Africa. A purposive sample of 1392 employees was selected. After career conversations/interviews were conducted, information was recorded on the institutions' electronic system. The participants were $53.6 \%=$ Black, $38.9 \%=$ White, $7.5 \%=$ other; $54.5 \%=$ female; and $45.5 \%=$ male). The academic management and primary support categories represented $90.9 \%$ and $46.5 \%$ respectively of the population.

\section{Measuring instrument}

An element of qualitative data was used through structured, face-to-face interviews (conversations). Employee responses were recorded in a structured and uniformed manner. A career-planning conversation framework was used by each line manager to focus on the employee's current goals (to determine whether the individual would like to make a vertical or horizontal career move) and "career preference" based on Schein's (Schein, 1978, 1990, 1996) career anchors table. The career conversation framework made provision for choosing between the three career enablers and for the purpose of the aim of this research, only the results pertaining to "career preference" were utilised. Table 1 presents the career preferences table utilised during the interview (career conversations). Line managers' rankings of the three top career preferences of an employee were also accessed.

\section{Research procedure}

Permission to conduct the study was obtained from the management of the participating institution. Participation was not voluntary as the discussions formed part of the institution's performance management process. The objectives were explained to the participants by their line managers. The results were captured and consolidated with an electronic system, administered by the organisation's development directorate via personalised e-mail messages to all line managers. The line managers were requested to use a career conversation framework (structured interviews with clear guidelines) and to record and capture the responses on the electronic system. Confidentiality and anonymity were assured by ensuring that no names were attached to results captured on the electronic system. 


\section{Data analysis}

The eight career anchor indicators (35 items) were formulated using Schein's (1978) definitions. All the enabling actions were analysed by means of an exploratory factor analysis to determine their fit in the eight career anchors model and to develop an organisational-specific three-factor career-enabling framework. To assess whether the data set was suitable for factor analysis, the Kaiser-Meyer-Olkin measurement of sampling adequacy (KMO) and the Bartlett's test of sphericity were conducted. Table 2 provides a summary of the results. From Table 2 it is evident that the data set was suitable for a factor analysis, as the Kaiser-Meyer-Olkin Measure of Sampling Adequacy index reported 0.93, which is much higher than the suggested 0.6 minimum value for good factor analysis. Bartlett's test of sphericity yielded a significant value (0.00), with $p<0.05$ considered appropriate for the factor analysis (Tabachnick \& Fidell, 2007). ANOVA was used to examine group differences in order to compare mean scores on a five point Likert scale. A Scheffe post hoc test was used to determine the pairs of groups that were different. The accepted level of significance was $p<0.05$. Practical significance of differences in means between the groups was determined (Ravid, 2010).

\section{Results}

Table 3 presents the descriptive statistics on the study variables. Three career enablers were identified to assist management with the career conversations within the institution.

\section{Career Functions}

As can be seen from Table 3, the self-transcendence pole contains items related to Schein's technical/ functional anchor and includes domains such as specialised training (TF1), remain in specialised area (TF2), specialised projects (TF3), expert, specialised mentoring (TF4), further studies (TF5) and specialised conferences (TF6). The self-enhancement pole contains three career anchors of Schein, namely general managerial, entrepreneurial creativity and pure challenge. Domains included here are inter alia responsibility and exposure (general managerial), entrepreneurial skills training and tasks with additional remuneration (entrepreneurial creativity) as well as a variety of tasks and stimulating and difficult problems (pure challenge)(Coetzee \& Schreuder, 2009). 
Table 1. Career preference table

\begin{tabular}{|c|c|c|}
\hline Career preference area & Item no. & Possible actions \\
\hline Technical/functional (TF) & $\mathrm{TF}_{1}$ & Provide specialised training programmes \\
\hline $\begin{array}{l}\text { Seeks the opportunity to apply skills in a } \\
\text { technical or functional area and to continue to }\end{array}$ & $\begin{array}{l}\mathrm{TF}_{2} \\
\text { area of }\end{array}$ & $\begin{array}{l}\text { Remaining in my specialised area as opposed to being promoted out of } \\
\text { expertise }\end{array}$ \\
\hline develop those skills to an even higher level & $\mathrm{TF}_{3}$ & Specialised projects \\
\hline & $\mathrm{TF}_{3}^{3}$ & Provide expert, specialised mentoring and coaching advice \\
\hline & $\mathrm{TF}_{4}$ & Encourage employees to further their studies \\
\hline & $\mathrm{TF}_{5}$ & Send staff to relevant conferences \\
\hline General managerial (GM) & $\mathrm{GM}_{1}$ & Give high levels of responsibility \\
\hline Seeks the opportunity to climb to a level high & $\mathrm{GM}_{2}$ & Empowerment \\
\hline $\begin{array}{l}\text { enough in an organisation to enable the } \\
\text { integration of others' efforts across functions }\end{array}$ & $\begin{array}{l}\mathrm{GM}_{3} \\
\text { at all le }\end{array}$ & $\begin{array}{l}\text { Give exposure to supervising, influencing, leading, and controlling people } \\
\text { vels }\end{array}$ \\
\hline and to be responsible for the output of a & $\mathrm{GM}_{4}$ & Leadership development programmes \\
\hline particular unit of the organisation & $\mathrm{GM}_{5}$ & Send staff to relevant conferences \\
\hline & $\mathrm{GM}_{6}$ & Networking \\
\hline Autonomy/independence (AU) & $\mathrm{AU}_{1}$ & Job rotation \\
\hline Seeks the opportunity to define work in one's & $\mathrm{AU}_{2}$ & Job enlargement \\
\hline own way. Seeks jobs that allow flexibility & $\mathrm{AU}_{3}^{2}$ & Implementation of job enrichment programmes \\
\hline & $\mathrm{AU}$ & Exposure to problem solving opportunities \\
\hline & $\stackrel{4}{\mathrm{~A}} \mathrm{U}_{5}$ & Management-by-objectives \\
\hline & $\mathrm{AU}_{6}$ & Projects \\
\hline & $\mathrm{AU}_{7}^{\circ}$ & Consulting \\
\hline Security/stability (SE) & $\mathrm{SE}_{1}$ & Lateral transfer with more secure working circumstances \\
\hline $\begin{array}{l}\text { Seeks employment security from a job or } \\
\text { organisation. Concerned about financial security }\end{array}$ & $\mathrm{SE}_{2}$ & $\begin{array}{l}\text { Provide security through guaranteed work, benefits, a good retirement } \\
\text { programme, etc. that will give long-run stability }\end{array}$ \\
\hline
\end{tabular}

organisation. Concerned about financial security

\section{Entrepreneurial creativity (EC)}

Seeks the opportunity to create an organisation or enterprise of one's own, taking risks to overcome obstacles

Service/dedication to a cause (SV) Seeks the opportunity to pursue work that achieves something of value, such as helping others, solving environmental problems and so on

\section{Pure challenge (PC)}

Seeks the opportunity to work on solutions to seemingly unsolvable problems, to win out over tough opponents or to overcome difficult obstacles

\section{Lifestyle (LS)}

Seeks a situation that permits the integration of personal needs, family needs and the requirements of the job

$\mathrm{SE}_{3} \quad$ Remain in present geographical location rather than receive a promotion or new job assignment in another location

$\mathrm{SE}_{4} \quad$ Ensure the least possible disruption to work/life balance and job uncertainty

$\mathrm{EC}_{1} \quad$ Provision of entrepreneurial training skills programmes

$\mathrm{EC}_{2} \quad$ Channel passion into a business

$\mathrm{EC}_{3} \quad$ Provide challenging tasks with additional remuneration and benefits

$\mathrm{SV}_{1} \quad$ Provide relevant training programmes

$\mathrm{SV}_{2} \quad$ Provide staff with support they need

$\mathrm{SV}_{3}$ Because service or dedication is crucial involve the employee in community

$\mathrm{SV}_{4} \quad$ Use skills to make the world a better place to live and work in, by involving the employee in support groups and other social support projects Provide employees with greater variety of tasks

Provide constant stimulating and difficult problems

Assign employee to work on problems that are almost insoluble and of a complex nature

Allow employee to plan his/her own work rosters and daily activities Develop a career that permits continuous pursuance of own lifestyle, because choosing and maintaining a certain lifestyle is more important than career success Careers must be integrated with the rest of life flexibility

Desire to work with organisations that accept and promote balance; some individuals unwilling to relocate for reasons of life balance 


\section{Structure of career enablers}

A principal components analysis with Varimax rotation (Garcia \& Rivera, 2013) was performed and factor loadings are shown in Table 3. With a cut-off point of 0.50 for inclusion in the interpretation of a factor, 28 of the 35 variables (items) loaded on the factors $F_{1}, F_{2}$ and $F_{3}$, consisting of 6, 11 and 11 items respectively. The three factors explain respectively $7.26 \%, 6.20 \%$ and $3.89 \%$ of the variance. The current study showed that the three factors (selftranscendence, self-enhancement and self-conservation) were extracted, all of which had a statistically significant relationship with each other.

The descriptive statistics, coefficient and inter-item correlations of the institution's three-factor career-enabler framework are reported in Table 4. As can be seen from Table 4, all the scores of the factors are normally distributed since the skewness and kurtosis for the factors do not exceed the critical values of 2.00 and 7.00 respectively. The negative skewness values that range between -0.52 and -1.14 are an indication that the distribution has relatively few small values and tails off to the left. This negative skewness contributes to the relatively high mean scores of the constructs. The Cronbach's alpha coefficient of the factors in Table 4 is acceptable if the guideline of $\alpha>0.70$ (Nunnally \& Bernstein, 1994) is applied, as well as the interitem correlations $(0.15<r>0.50)$ (Clark \& Watson, 1995). It is only $\mathrm{F}_{2}$ that is slightly above the upper limit of the interitem correlations of 0.50 . It would thus appear that the factors have sufficient levels of internal consistency. Table 5 presents the inter-correlations of the factors for the higher education institution career-enabler framework. From Table 5 it can be seen that three factors were identified within the higher education-specific career-enabler factor structure. All of these factors had a statistically significant relationship with each other.

Table 2. Kaiser-Meyer-Olkin measure of sampling adequacy and Bartlett's test of sphericity

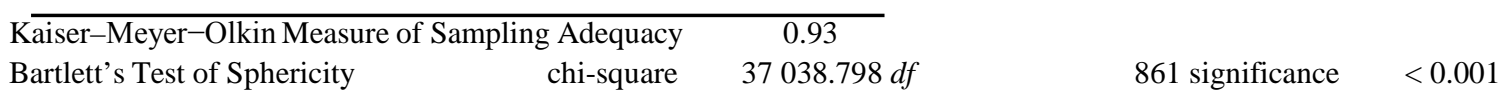

Ther factor withdrawal and Varimax rotation on the items of the Career-Enabler Framework

\begin{tabular}{|c|c|c|c|c|c|}
\hline Factor & Item no. & Item & $\mathrm{F}_{1}$ & $\mathrm{~F}_{2}$ & $\mathrm{~F}_{3}$ \\
\hline \multirow{6}{*}{$\begin{array}{l}\text { Self-transcendence through } \\
\text { technical self-affirmation }\end{array}$} & $\mathrm{TF}_{1}$ & Specialised training & 0.79 & & \\
\hline & $\mathrm{TF}_{2}^{1}$ & Remain in specialised area & 0.54 & & \\
\hline & $\mathrm{TF}_{3}^{2}$ & Specialised projects & 0.71 & & \\
\hline & $\mathrm{TF}_{4}$ & Expert, specialised mentoring & 0.71 & & \\
\hline & $\mathrm{TF}_{5}$ & Further studies & 0.61 & & \\
\hline & $\mathrm{TF}_{6}$ & Specialised conferences & 0.74 & & \\
\hline \multirow{11}{*}{$\begin{array}{l}\text { Self-enhancement through } \\
\text { stretched goals }\end{array}$} & $\mathrm{GM}_{1}$ & Responsibility & & 0.78 & \\
\hline & GM2 & Empowerment & & 0.74 & \\
\hline & GM3 & Exposure & & 0.78 & \\
\hline & GM4 & Leadership development & & 0.73 & \\
\hline & GM5 & Relevant conferences & & 0.75 & \\
\hline & EC1 & Entrepreneurial skills training & & 0.55 & \\
\hline & EC2 & Passion in business & & 0.54 & \\
\hline & EC3 & Tasks with additional remuneration & & 0.53 & \\
\hline & PC1 & Variety of tasks & & 0.59 & \\
\hline & PC2 & Stimulating and difficult problems & & 0.58 & \\
\hline & РC3 & Assign to complex tasks & & 0.60 & \\
\hline \multirow{11}{*}{$\begin{array}{l}\text { Self-conservation through work } \\
\text { motives and needs }\end{array}$} & AU2 & Job enlargement & & & 0.63 \\
\hline & AU3 & Job enrichment & & & 0.63 \\
\hline & AU4 & Exposure - problem solving & & & 0.56 \\
\hline & AU5 & Management-by-objectives & & & 0.57 \\
\hline & AU6 & Assign to projects & & & 0.53 \\
\hline & SE2 & Job and financial security & & & 0.62 \\
\hline & SE4 & Least disruption to work-life balance & & & 0.60 \\
\hline & LS1 & Plan own roster and daily activities & & & 0.70 \\
\hline & LS2 & Lifestyle more important than career & & & 0.57 \\
\hline & LS3 & Career integrated with life flexibility & & & 0.74 \\
\hline & LS4 & No relocation because of promoting balance & & & 0.71 \\
\hline Explained variance & & & 7.26 & 6.20 & 3.89 \\
\hline
\end{tabular}

Table 4. Descriptive statistics, and coefficient and inter-item correlations of the three-factor career-enabler framework

\begin{tabular}{|c|c|c|c|c|c|c|c|}
\hline No of items & Factor & Mean & SD & Skewness & Kurtosis & Cronbach alpha $(\alpha)$ & $r$ (average) \\
\hline 6 & $\mathrm{~F}$ & 4.18 & 2.00 & -1.14 & -0.02 & 0.84 & 0.49 \\
\hline 11 & $\mathrm{~F}$ & 6.83 & 3.86 & -0.52 & -1.06 & 0.91 & 0.51 \\
\hline 11 & $\mathrm{~F}$ & 7.15 & 3.60 & -0.76 & -0.70 & 0.89 & 0.46 \\
\hline
\end{tabular}

Factor designations: $\mathrm{F}_{1}$ : Self-transcendence through technical and specialised affirmation

$\mathrm{F}_{2}$ : Self-enhancement through stretched goals

$\mathrm{F}_{3}$ : Self-conservation through work motives and needs

Table 5. Inter-correlations of the factors of the Career-Enabler Framework 


\begin{tabular}{|c|c|c|c|}
\hline & \multicolumn{3}{|c|}{$\mathrm{F}_{1}$} \\
\hline$F_{1}$ & 1.00 & & \\
\hline $\mathrm{F}_{2}$ & 0.48 & 1.00 & \\
\hline $\mathrm{F}_{3}$ & 0.44 & 0.56 & 1.00 \\
\hline
\end{tabular}

\section{Discussion}

The rationale for this study was three-fold: to explore the number and nature of career orientations that individuals from a higher education institution hold; to determine the three most important career preferences for employees within a higher education institution and to develop a career-enabler framework that will assist the institution with career conversations. Exploring employees' career orientations can also help organisations to establish the most appropriate career interventions for rewarding and retaining talented staff (Erdoğmuş, 2004). Knowledge of employees’ career orientations and career enablers can assist management in the understanding of their employees' internal career satisfaction. It can also facilitate employers in designing appropriate reward, recognition and promotion systems (Erdoğmuş, 2004).

This research makes an important contribution to the career field by proposing an original higher education institution career-enabler framework that combines theoretical logic (Circular Model of Career Anchor Structure) with confirmation through convincing empirical evidence. This framework is depicted in Figure 1. The Circular Model of Career Anchor Structure developed by Wils, Wils and Tremblay (2010) shows that several career anchors are complementary (e.g., creativity and challenge) while others are conflicting (e.g., challenge and security). Contrary to these findings, the higher education career-enabler framework is only based on three pillars and only incorporates seven of Schein's (1978, 1990, 1996) eight career orientations. Findings from this study concur with findings from Feldman \& Bolino (1996), which led them to reconceptualise Schein's (Schein, 1978, 1990, 1996) eight career anchors into three distinctive groups. Interestingly, the career orientation: service/dedication to a cause does not form part of the career-enabler framework. A possible explanation for this could be that the participants were not only academic employees, but also employees from the support group - only $20.4 \%$ of the respondents were from the academic environment. Furthermore, considering literature discussed below regarding people's dedication to work for a cause, it can be assumed that the support group might not value their career as a service/dedication. The other assumption is that due to diversity within the support group, people may prefer to focus on their own development in order to specialise within their careers, therefore a more inter-personal focus than an intra- personal focus to render a service was observed. People who hold the service or dedication to a cause career orientation (or values-based career anchor as reconceptualised by Feldman \& Bolino, 2000) are motivated to achieve value in the areas of the world in which they are involved (Schein, 1985; 2006). The main concern of these individuals is to help others. They also view their careers as a calling and possess a strong sense of purpose (Coetzee \& Schreuder, 2009). This is of importance within a higher education institution considering that the academic staff is supposed to help students achieve success in their studies.

Research conducted by Coetzee \& De Villiers (2010) indicates that the core values of this career anchor are to influence others, and the freedom to operate autonomously in the pursuit of one's personal values or higher life purpose/goals. Considering that Schein (2006) links the service or dedication to a cause career orientation with the helping professions such as teaching (Du Toit \& Coetzee, 2012), it is surprising that this career orientation does not form part of the career enablers for employees at the institution. 


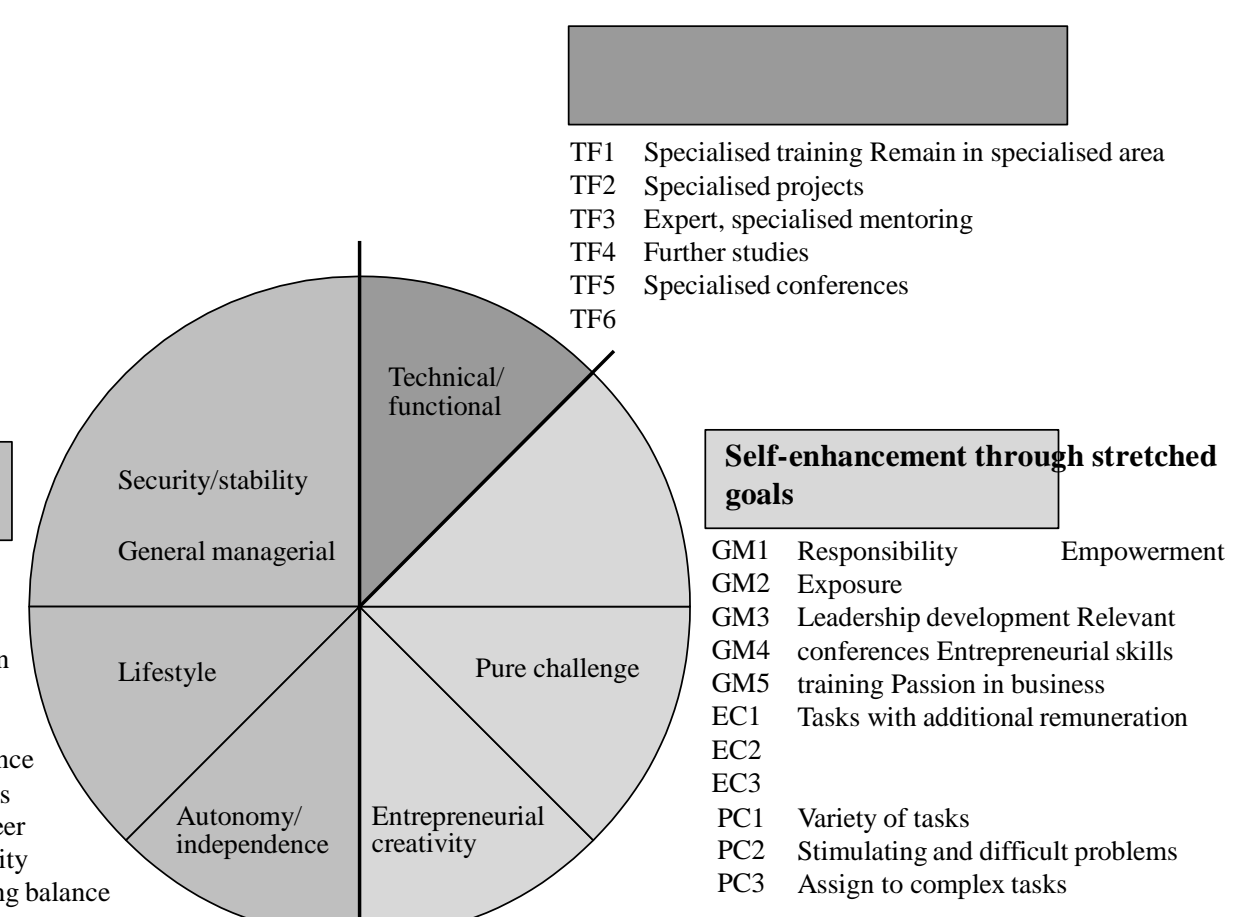

Self-co
throug
AU2
AU3
AU4
AU5
AU6
SE2
SE4
LS1
LS2
LS3
LS4

LS4

Job enlargement
Job enrichment
Exposure - problem solving
Management-by-objectives Assign
to projects
Job and financial security
Least disruption to work-life balance
Plan own roster and daily activities
Lifestyle more important than career
Career integrated with life flexibility
No relocation because of promoting balance

TF1 Specialised training Remain in specialised area

TF2 Specialised projects

t, specialised mentoring

TF5 Specialised conferences

Figure 1. Higher Education Career-Enabler Framework

\section{Limitations of the study and suggestions for future research}

Because the present study has been limited to a population employed within a higher education institution in the South African organisational context, the findings cannot be generalised to other occupational contexts. In addition, due to the exploratory nature of the research design, this study cannot yield statements about causation. For this reason, findings from this study need to be replicated with broader samples across other educational institutions and economic sectors before final conclusions are drawn about implementation of a career-enabler framework. Further studies should consider the influence biographical differences have on the institution's career-enabler framework including the role of social networks.

\section{Conclusion}

The understanding of career anchors can help organisations deal with career development as well as career interventions more successfully. The findings of this study show that employees from a higher education institution chose three factors as career enablers. These seem to explain and drive the enactment of the dominant career motives and values underlying their dominant career orientations. In this regard, the findings of the study extend the career anchor literature, particularly research on anchors, which makes it easier for the human resources professionals who are responsible for intervention development and policy formulation, as well as for the line managers who have to manage individual career interventions. 


\section{References}

Baruch, Y. (2003). Transforming careers: from linear to multidirectional career paths, Career Development International, 9(1), 48-73.

Bay, S., \& Lim, K. M. (2006), Correlations of multiple intelligences and emotional intelligence: A closer analysis of theoretical assumptions, The Korean Journal of Thinking \& Problem Solving, 16(1), 53-64.

Clark, L., \& Watson, D. (1995), Constructing validity: Basic issues in objective scale development. Psychological Assessment, 7 , 309-319.

Coetzee, M. (2006), Career planning in the 21st century: Strategies for inventing a career in a dejobbed world of work, Juta, Cape Town.

Coetzee, M. (2007), Exploratory factor analyses of the Psychological Career Resources Inventory, Unpublished research report, University of South Africa, Pretoria, South Africa.

Coetzee, M. (2008), Psychological career resources of working adults: A South African survey, SA Journal of Industrial Psychology, 34(2), 32-41.

Coetzee, M., \& De Villiers, M. (2010), Sources of job stress, work engagement and career orientations of employees in a South African financial institution. Southern African Business Review, 1(1), 27-57.

Coetzee, M. \& Schreuder, AMG. (2008), A multi-cultural investigation of students' career anchors at a South African higher education institution, SA Journal of Labour Relations, 32(2), 45-65.

De Villiers, M. (2009), The relationship between employee wellness and career anchors, Unpublished master's dissertation, University of South Africa, Pretoria, South Africa.

Du Toit, D. \& Coetzee, M. (2012), Archetypal values of science and engineering staff in relation to their career orientations, South African Journal of Industrial Psychology, 38(1), 1-15

Erdoğmuş, N. (2004), Career orientations of salaried professionals: The case of Turkey. Career Development International, 9(2), 153-175.

Feldman, D.C., \& Bolino, M.C. (1996), Careers within careers: Reconceptualising the nature of career anchors and their consequences. Human Resource Management Review, Vol 6, No. 2, 89-112.

Feldman, D.C., \& Bolino, M.C. (2000), Career patterns of the self-employed: Career motivations and career outcomes, Journal of Small Business Management, Vol. 38, 53-67.

Ferreira, N. (2012), Constructing a psychological career profile for staff retention. Unpublished doctoral dissertation, University of South Africa, Pretoria.

Ferreira, N., Basson, J., \& Coetzee, M. (2010), Psychological career resources in relation to organisational commitment: An exploratory study, South African Journal of Human Resource Management, Vol. 8, No. 1, 1-10.

Ferreira, N., \& Coetzee, M. (2010), Psychological career resources and organisational commitment: Exploring socio demographic differences, South African Journal of Labour Relations, Vol. 34, No. 2, 25-41.

Garcia, J.L. \& Rivera, D.G. (2013). Critical success factors for Kaizen implementation in manufacturing industries in Mexico. International Journal Advanced Manufacturing Technology, 6(2), 283-295.

Gardner, H. (1983), Frames of mind, New York: Basic Books. Kidd, J.M., Jackson, C., \& Hirsch, W. (2003). The outcomes of effective career discussion at work. Journal of Vocational Behavior, 62, 119-133.

Nunnally, J., \& Bernstein, I. (1994), Psychometric theory.(3rd ed), McGraw-Hill: New York.

Rajesh, S. \& Ekambaram, K. (2012), The impact of career enablers on women's workforce participation in India. FLEXI careers India: Viewport. Retrieved from http:// www.flexicareersindia.com/research-study/viewport- careerenablers.pdf.

Ravid, R. (2010), Practical statistics for educators (4th ed), University Press of America: Lanham.

Schein, E.H. (1975), How Career Anchors Hold Executives to Their Career Paths, Personnel, Vol. 52, 165-178.

Schein, E.H. (1978), Individual Careers. In J. Lorsch (Ed.), Handbook of organizational behaviour (pp 155-171, Prentice-Hall, Englewood Cliffs, NJ.

Schein, E.H. (1985), Career Dynamics: Matching Individual and Organizational Needs, Reading, MA: Addison-Wesley.

Schein, E.H. (1990), Career anchors: Discovering your real values, Pfeiffer \& Company, San Diego.

Schein, E.H. (1996), Career anchors revisited: Implications for career development in the 21st century, Academy of Management Executive, Vol 10, No. 4, 80-88.

Schein, E.H. (2006), Career anchors participants’ handbook, Pfeiffer, San Francisco. 
Tabachnick, B.G. \& Fidell, L.S. (2007), Using multivariate statistics, (5 ${ }^{\text {th }}$ ed.), Pearson Education, Boston.

Wils, L., Wils, T., \& Tremblay, M. (2010). Toward a career anchor structure: An empirical investigation of engineers, Relations industrielles/Industrial Relations, Vol. 65, No. 2,236-256. 